\title{
Group blogs: Documenting collaborative drama processes
}

\author{
Robyn Philip \\ Charles Darwin University \\ Jennifer Nicholls \\ Macquarie University
}

\begin{abstract}
The use of blogging (online diaries), to support student learning and reflection has increasingly been adopted for assessment purposes in higher education. The relative ease of use and accessibility of the tools indicate that these social networking applications are, potentially, a convenient means of documenting and sharing individual student learning. There are relatively few instances, however, of the use of group blogs for this purpose, that is where ownership of the blog is a collective enterprise rather than an individual one. This case study examines the use of group blogs to support collaborative processes in drama for the activity known as playbuilding, or group devised theatre. The efficacy of the group blog is compared with the alternative it replaces - the individual, paper based journal. Using an action research methodology, the findings are based on the results of focus groups, interviews, surveys and blog entries, and raise issues about the affordances of Web 2.0 technologies, support for creative group work, student engagement and reflective practice.
\end{abstract}

\section{Introduction}

Group blogging, where ownership of the blog is a collective enterprise, rather than an individual one, is a relatively new innovation, and there is little in the literature about its impact and efficacy in the educational context. This case study is an evaluation of the process of group blogging within a drama unit at an Australian higher education institution, where the aim was to replace the traditional individual reflective journal as an assessment task, with a group blog, and to evaluate the effectiveness of reflection within that collaborative environment. The student cohort was a mix of third-year creative arts students, pre-service teachers and students from other disciplines. These were, therefore, predominantly students who were likely to use technology in their future workplace or teaching practice. Further, the project aimed to investigate the processes of student reflection, comparing the blogging with individual, print based journal writing; the contribution of group blogging to engagement of students in playbuilding; and the benefits and limitations of group blogging as a collaborative form of assessment. The research builds on work conducted over a number of years with university drama students, investigating engagement within varied elearning spaces, including blended, face to face and fully online environments. In this paper we discuss the meaning of playbuilding in drama, the context for the change of assessment, the need to improve students' reflective practice, the methodology of the research, and the outcomes of the study. The conclusion provides a summarised response to the research questions. 


\section{Playbuilding and reflection}

Playbuilding (also known as group devised theatre) is an ongoing collaborative process whereby groups of students (actors) work together to devise an original performance by combining drama forms and incorporating elements of drama and theatre. Students create, produce and perform the play to audiences including peers, family, friends, examiners and the general public. It can be conceptualised as "a sustained exploration of ideas or images" where students move in and out of character, collaborating and "critically reflect[ing] upon a fictional world of their own creation" (Simons (2004, p.1). Like the pieces of a jigsaw puzzle, each student contribution has its own individual "shape, color and feature" (Simons (2004, p.1), and through the collaborative and challenging processes of playbuilding the performance is drawn together into a meaningful whole. This "process-oriented ensemble work ... requires enthusiasm, discipline, and endurance" (Magnat, 2005, p.81). It is no easy task. As well as confidence in one's self, the group must believe that they can bring their "artistic project to maturity" Magnat (2005, p.81). Group identity and cohesion are critical.

Playbuilding is taught throughout the world in secondary and tertiary institutions. It is common for students of this drama form to produce a reflective journal or diary to accompany the practical work of devising an original play. The aim of the journal is to document and analyse the process of devising a play from inception through to performance. The journal is generally an assessable component of the unit and is typically completed over time as an individual activity. Usually only the student and the teacher share the journal. However, students, and even professionals, ( $\mathrm{O}^{\prime}$ Toole, 2006) seldom understand how to create and structure a reflective journal. "The automatic response of a beginner to the task is either just to describe what happened in a simplistic narrative of the explicit action, or to dive into unstructured stream-ofconsciousness personal feelings about the experience" (O'Toole, 2006, pp.107-108). There is often insufficient deep "analytical reflection", i.e. how something was done, or "evaluative reflection", how well something was done (Cowan, 1998, p.17). There is a need to challenge many students to move beyond stream of consciousness description and explanation of the particular, towards more formalised interpretation and generalisation. Dacre and Mackey's (1999, p.69) model for reflection is a useful framework for informing this. Building on the work of Schon and others, the framework encourages critique of the group and its context, self interpretation, and artistic and theoretical reflection. The model is not only useful for drama and theatre studies but is readily adaptable for other disciplines where students must engage in group work and reflection. The steps are as follows:

1. Reflect on the structure and workings of the group;

2. Reflect on your own role as an autonomous individual member of the group;

3. Place the work within the relevant theoretical tradition; and

4. Reflect on your own narrative as a practitioner, i.e. examine the stories and generalisations you have created about the process and your professional context.

In order to encourage students to reflect more purposefully and deeply along the lines recommended by Dacre and Mackey, and better engage with the process, a change was required: the value of individual reflective journals as the best tool for developing critical thinking skills in this context was questioned. Also, we wanted a more dynamic means of capturing and documenting the reflective process. We had evidence from previous evaluation studies on the impact and effectiveness of online collaborative 
writing tasks which gave us some clues. The research showed that suitably structured collaborative online writing tasks, individually assessed, could strengthen students' grasp of theoretical concepts and disciplinary discourse, build the writing skills of weaker students as they observed the writing style of more competent peers, and reinforce the skills required for group work (Nicholls \& Philip, 2001; Philip \& Nicholls, 2007).

Given that Web 2.0 social networking tools are increasingly used by Australian university students (Kennedy et al., 2008), it seemed there was an opportunity to incorporate these technologies into a reconceptualisation of the assessment task, and use the affordances of the web to share ideas amongst students about playbuilding. Aware that individual blogs can suffer from the same problem of uncritical and stream of consciousness writing as print based journals, we decided to investigate the potential of group blogging. Compared with individual blogs, we predicted that the online groups, based on the in-class playbuilding groups, would offer a more manageable workload from the teacher's point of view for monitoring and marking. In addition, the blogs might encourage better synthesised and considered contributions from individuals, given the more public nature of the writing space. Further, group blogging offered support for creative collaborative processes, central to group work and playbuilding; a platform whereby visual and multimedia elements could be more readily integrated into the reflective process; and tools to enable students to share and make visible their thinking, over a period of time.

Table 1: Comparison of individual, paper based journal with group blog

\begin{tabular}{|l|l|}
\hline \multicolumn{1}{|c|}{ Previous model (pre 2008): Journal/diary } & \multicolumn{1}{|c|}{ New model (2008): WordPress blog } \\
\hline $\begin{array}{l}\text { Learning outcome: To document individual } \\
\text { contribution, process, creativity and reflection }\end{array}$ & $\begin{array}{l}\text { Learning outcome: to document individual and } \\
\text { group contribution, process, creativity and } \\
\text { reflection }\end{array}$ \\
\hline Audience: Student and teacher & $\begin{array}{l}\text { Audience: Student, group members, other } \\
\text { selected peers, and teacher and professional } \\
\text { colleagues }\end{array}$ \\
\hline $\begin{array}{l}\text { Individual and personal } \\
\text { Individual and collaborative }\end{array}$ \\
\hline $\begin{array}{l}\text { Technologive input } \\
\text { required }\end{array}$ & $\begin{array}{l}\text { Tool for critical reflection, documenting } \\
\text { creative input, collaboration, facilitation of } \\
\text { playbuilding process with continuous impact }\end{array}$ \\
\hline Stand alone & $\begin{array}{l}\text { Technology: Web based, high tech, basic } \\
\text { training required }\end{array}$ \\
\hline $\begin{array}{l}\text { Integrated with traditional individual study } \\
\text { habits }\end{array}$ & $\begin{array}{l}\text { Active integration with other digital } \\
\text { information sources }\end{array}$ \\
\hline $\begin{array}{l}\text { Media: Print based, text, diagrams, drawings, } \\
\text { photos, printed web pages and web references, } \\
\text { photocopied materials, quotes from academic } \\
\text { journals, handwritten or typed }\end{array}$ & $\begin{array}{l}\text { Integrated with student Web 2.0 social } \\
\text { networking habits and tools }\end{array}$ \\
\hline $\begin{array}{l}\text { Issues: Often completed at last moment, value } \\
\text { of task and reflective process not fully } \\
\text { ynderstood, engagement variable } \\
\text { and quotes from academic journals, typed }\end{array}$ \\
\hline
\end{tabular}

As a result, the traditional, paper based reflective journal was omitted from the assessment regime, and replaced by a collaborative online blogging task. A comparison of the characteristics of the individual, paper based journal and the group 
blog is given in Table 1. The focus of this paper is evaluation of the change of assessment and the associated technologies.

Overall, the project can be characterised as the documentation of collaboration, reflection and creativity - enabled by good design, facilitation by teacher and students, and the use of social networking technologies (see Figure 1).

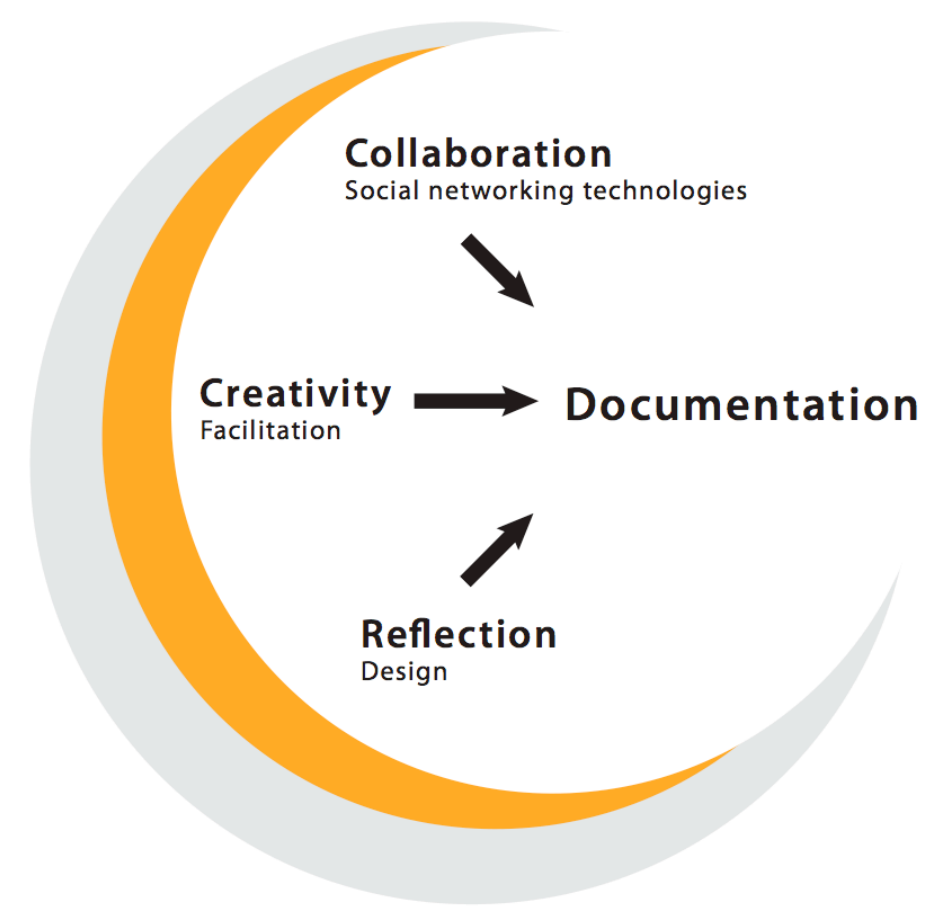

Figure 1: The documentation of collaboration, reflection and creativity

\section{Methodology}

In keeping with previous research into drama education and the use of e-learning technologies, an action research methodology was adopted. Research outcomes and action that promotes change (McTaggart, 1991) were pursued concurrently. In action research, participants are viewed as active partners working with researchers to improve the way issues are addressed. Based on the Kember and Kelly (1993) model, our research moved through iterative and documented cycles of planning, acting, observing and reflecting.

The process is participatory, so that students' ideas about, for example, educational design and the use of technology from previous units were incorporated into the planning cycle, and the reflections of current participants in the research (teachers and students), the immediate stakeholders, were sought continually in a formative process which led to action and change - i.e. methods for improving critical thinking and playbuilding skills. 
The questions underpinning the research were as follows:

- In what ways does group blogging differ from individual journal reflection in drama?

- How does group blogging contribute to or limit engagement in playbuilding in drama?

- What are the benefits and limitations of group blogging as a collaborative form of assessment?

A triangulated approach was used to gather data from three main sources: two print based surveys, focus groups and interviews, and student texts, i.e. blog entries and essays. In addition, reflections and systematic documentation of the process maintained by the researchers, and statistics from the WordPress weblogs were analysed.

Two anonymous surveys were administered at the end of the semester in which the blogging was trialled (June 2008). The first survey focussed specifically on issues regarding the student experience of using the blogs, including comparison of blogging with individual reflective journal writing, the benefits and limitations of using the blog, technical issues and suggestions for improvements. The second survey was a standard template used by the university to collect feedback on learners' experience of the unit generally, regarding goals and standards, organisation, feedback and support, relevance of the assessment and workload. Both surveys posed 17 questions to the students, and included a mix of multiple choice and open ended questions. The surveys were distributed in class and all 21 students responded to the blog survey; 20 responded to the learner experience questionnaire.

All students were invited to participate in one of several scheduled focus groups. Two focus groups of one hour each were conducted and 7 students attended. One student unable to attend either session agreed to a phone interview. The goal of the focus groups was to expand on the preliminary findings from the survey data. Data from the focus groups, student interview, an interview with the unit coordinator, comments from the surveys, the essays and blogs, were coded and analysed with the aid of qualitative analysis software (NVivo). The three student blogs were reviewed and analysed for evidence of social, cognitive and creative engagement with the playbuilding process, and evidence of student reflection on all aspects of the playbuilding process and their own learning. Throughout the whole process the authors met regularly to observe, plan, act, reflect as per the usual requirements of action research.

\section{Blogging in an educational context}

The literature is developing on blogging and its place as a tool for the promotion of social and personal activities, and communication within learning communities (e.g. Anderson, 2007; Godwin-Jones, 2003; Nardi et al., 2004), as is the literature on blogging within educational contexts (e.g. Chong, 2008; Hurlburt, 2008; Instone, 2005; Tekinarslan, 2008; Williams \& Jacobs, 2004). However, there is less reported on the experience of 'group blogging', where ownership of the space is collective. One of the key characteristics of Web 2.0 communication tools, such as blogs, is their capacity to support users as producers of content (not merely as consumers), and the power of these technologies to underpin networks for short or long periods of time. Chong, working from a distributed cognition rather than a cognitivist perspective, 
conceptualises blogging in relation to learning communities and their cultures. Drawing on the work of Lave and Wenger, the idea of "distributedness" (Lave \& Wenger, 1991) is discussed in relation to blogging, where cognition is spread individually and collectively amongst the learning community. This includes the individuals within the group, the social and cultural elements of the group and the activity itself, all of which comprise the collaborative and distributed learning setting.

Many authors describe the social learning that takes place in collaborative spaces such as blogs, and the importance of personal ownership of the space (see Anderson, 2007; Chong, 2008; Nardi et al., 2004; Tekinarslan, 2008). Nardi et al. describe blogging as a support for cognition, and use Vygotsky's expression "thinking by writing" (Nardi et al., 2004, p.227), meaning that the act of writing promotes thinking and understanding, and the blog becomes a bridge between the writer and the reader. Some researchers point out the under-utilisation of educational blogs that are not well integrated into learning activities (e.g. Tekinarslan, 2008) and Nardi et al. note that, like other online communication tools, small-group blogs with multiple authors can have problems where individual voices become dominant, not only because of the personal writing style of individuals, but because of the formatting of blogs, where comments to original posts are displayed beneath main topic postings, so that some voices can become subsumed within a topic thread, displaying at a secondary level of importance. In our experience, it was not the format of the blog that was an issue for our students, as all members of the group blog had equal status in terms of creating the end product and equal rights to contribute at the first level of contribution to the blog. It was only group size that had a noticeable effect: if the group was small, group members had to make long posts or send extra posts to build a certain minimum level of discussion; if the group was large, students at times had to be more creative generating suggestions or ideas that had not already been expressed.

\section{The blogging challenge}

The new blogging activity for students in the third year unit required that, as in past years, learners divide into groups to devise an original play to be performed at the conclusion of the semester. This time, however, the self-selected groups had their own corresponding WordPress blog. Twenty one students participated and groups ranged in size from three, to eight to ten members. All students in each group were expected to contribute consistently to the blog over the semester. The analytical and reflective documentation for playbuilding was now to be jointly owned by the participants, along with face to face, group creative processes. Students were required to contribute their own individual comments and respond to the postings of others. A minimum submission of 2,000 words (or equivalent) to the blog over the semester was mandatory, ideally with contributions made at least once per week.

Students were encouraged to write in a journalistic style, that is, personal and informative with correct spelling and grammar. However students were also expected at times to refer to recommended or self sourced, theoretical readings, and draw widely from sources available via the web or created by students themselves, in support of their arguments and creative ideas. For example, students shared URLs to background material to inspire and provide a foundation for their plays, uploaded original and copyright free photos, linked to music and video files, and posted draft scripts. As a result students collaboratively built, rehearsed and deconstructed the performance making process in both face to face and online environments. 
Students were given access to all three blogs, but were only given "authoring" rights to their group blog. However any student was free to comment, critique and reflect on entries their peers sent to any of the three blogs. To maintain a level of privacy for the blogs, viewing permissions were set so that none of the blogs was listed in the main WordPress directory and search engines such as Google would not discover or list the blogs. Students could, however, distribute the URL for any of the three blogs if they wished to share the experience with friends - an option some students took up.

So as to provide timely feedback, students were assessed on their blog work twice during the semester according to the following assessment criteria:

- Reflective and analytical contribution to discussions;

- Facilitation and promotion of discussions;

- Effective use of readings and other resource material to support ideas;

- Clarity of written expression; and

- Creative approaches taken to blog submissions.

From these clear guidelines and assessment criteria a strong but flexible framework to support students' learning and creativity was established. Our experience and research over many years has demonstrated that time spent on the design of the unit, especially the assessment tasks, and the development of an engaging learning environment, is essential so that students have the tools and skills to work both independently and collaboratively as required throughout the unit. The students were given ownership and responsibility of their playbuilding and performance in every respect. The role of the teacher was a facilitative one, acting as "side coach" (Pierse, 1993), but never directing the group work. This was something the students had to control and manage themselves. Management of group dynamics is an important skill for all university graduates, it is not only important in drama.

\section{Results}

\section{Blogging as support for process and playbuilding}

The student cohort of this study was aged between 18 and 30: 10 were 18-20 years old; 9 were 21-29; and one was 30; 4 were male students and 17 were female. Only 1 student had never studied drama before. The rest had studied the subject at school and/or university. Most enrolled in the unit because they wanted to continue their drama studies (16). Only 5 students had never before kept a reflective journal for drama or any other subject.

Traditionally for playbuilding in drama, students work together in face to face settings - in class and, for our students, out of scheduled class time as well. They are expected to consider the following stages when planning for their performances: story, characterisation, structure, script, performance space, production elements (such as costumes, props and lighting) and marketing. With the introduction of the blogging task, these stages were also discussed, debated and planned in the online environment. This had enormous impact on the creative process. For example, rather than students spending (and sometimes wasting) class sessions searching for ideas for their performances, the students were able to source and share ideas through the blogs within hours of the first class. 
How good is it that we have come so far in just one week of nutting this thing out [on the blog]. In my experience, groups usually take a number of weeks to get a solid base to work with. (blog entry)

This group is the first performance group that I have worked in that has had something solid to work with from week one. I mean we had our plot, character names and even a name for the show all before the end of the first session together as a group. (blog entry)

Within weeks, students were using class time more effectively for improvisation and rehearsal because of the preparation that had occurred between classes via the blogs. For example, much of the collaborative building of scripts was documented on the blogs. Evidence from the data indicates that the blogs kept students on task, as they set themselves achievable goals each week and reflected on progress and issues. The assessment requirements ensured that each group member had a regular "presence" (Philip \& Nicholls, 2007), and opportunity to contribute. It was also an invaluable forum for normally time-consuming "housekeeping" issues. One student noted that "It inspired and guided the whole process of our performance" (blog survey); and another commented that, "It was really good to come in on Wednesday morning and just go bang! Let's start" (focus group).

The iterative pattern established between the online blog and in-class tutorial time, so important in the early stages of the projects, where students researched ideas, tested them with the group, reflected on the outcome, and planned the next steps, is evident from the following comments:

We divided our time - class time was when we worked and blog was where we discussed it ... What we had discussed in the blog fed into the work that we did, and the work inspired the discussions. (focus group)

There is evidence from the blogs that students were generally not adopting a surface approach to their reflection and critique. As the plays progressed, some students focused on, for example, the qualities of good drama, pushing their group members to deeper consideration of the issues. There is also evidence here of analytical reflection, rather than stream of consciousness, early draft writing.

I think we have enough to work with to construct our ideas into a narrative action performance. But we need to seriously consider the elements (focus, tension, mood, contrast, space, symbol, time and space) upon which we will create this environment and scenario (through costumes, lighting, music, sets/props etc...). Ok, so when we play build tomorrow, let's use the elements of drama and theatre as buzz words, to instigate a flow of ideas that ground themselves in achievable and grounded opportunities for our orchestra! (blog entry)

Students claimed the group blog was a more efficient means of communicating with group members, than for example, email. That a few of the students, in a subsequent unit of study, set up their own space out of class for group collaboration using social networking technologies and the model established for this unit, confirms that the tool was perceived as useful and relevant to at least some students. As many of the students in this cohort saw themselves as leaders, managing the group dynamics was challenging for them all - on or off the blog. For some, the blog was a place to clear up misconceptions in class or at rehearsal outside of class. "If you wanted to say something, we knew that everyone would get it [if you put it on the blog], everyone would understand and no one would paraphrase it." (focus group) 
For others, the reverse was true: it was in class where misconceptions from the written word on the blog were clarified. This reiterates the difficulties of group work and collaboration. It is a challenging process, and students need support to work through the issues themselves. Our observation was that the personal 'venting' of frustration with group functionality that students missed as they were not submitting an individual journal, was transformed into more constructive thought as students in the public space of the blogs were required to think through difficulties they were having with, e.g. an idea, production element or person, and argue a case for making changes.

\section{Learning, reflection and documentation}

Along with facilitating the playbuilt performances, the blogs were used by students to critically reflect upon and document the process as a whole. While the unit coordinator generally did not enter into the student conversations, she did, however, continually facilitate, scaffold and monitor student postings, for example reminding students to reflect on the process, and suggesting academic journal articles, theatre texts and other sources to consult as the plays developed. As students integrated these various resources, with particular reference to the style or genre of their play, they were encouraged to reflect on what Dacre and Mackey $(1999$, p.56) refer to as "the group and its context". Again, for traditional student journals, this is a task undertaken by students individually with little or no opportunity to share ideas with others, or to more deeply and critically reflect on drama processes and genres based on the discussions of others. The record of reflection is not documented and challenged or supported by others. In the old model the iterative "conversational framework" (Laurillard, 2002) tends to be missing at the point where the reflection processes are translated into written journal entries by the student.

Being challenged by others assists with the process of reconceptualisation, and the depth of critique. Students commented that writing for the blog was both more challenging and easier than writing in a print based journal. While the group provided more inspiration, and "something to work from" (focus group comment), the "group reflection" presented other challenges in terms of the need to accommodate more than one viewpoint, to argue succinctly, and to be answerable for any debate they participated in or initiated. The level of reflection and debate around the playbuilding process was, at times, at a depth not previously observed by the unit coordinator in traditional individual journals, and students themselves were aware of the pitfalls of uncritical journal writing. As one student commented:

The thing is, there's just no point to the journal. You're writing to yourself about stuff you already know, and with WordPress, even if you were doing that introspective reflection on playbuilding, at least you're sharing it with other people, and you talk about it, and you communicate about it. (focus group)

The limitations of the medium are brought to light in this comment comparing the journal and the blog:

It wouldn't have ended up looking the same way in a print journal. Like in a print journal, we could have stuck photos in there, or printed pictures off websites, or whatever but because I think we really wanted to capture all the elements of film noir which was our genre, ... it was more than just pictures that we had to take into mind, ... we wanted to look at mood and lighting and music and sound and that's so much easier to do, I think technologically and so it was a lot easier for us being able to do it on the blog. (focus group) 
It was this strong need to capture the individual qualities of each play as a way of documenting the final product that gave the blogs more impact than individual journals. As Simons (2004) says in her definition of playbuilding, it is "more than the sum of its parts" (p.11). The blogs gave students the opportunity to not only create and document the "parts", but also reflect on the final whole. In the essay students were required to write at the conclusion of the semester, one student wrote:

My own personal experience of the playbuilding process has been very fulfilling. Along with the in-class development, this unit has opened up the door to cyberplaybuilding communication. The blogs have been a successful asset in comparing commenting, criticising (positively) and expanding upon ideas throughout the semester ... This addition to the playbuilding process has made the experience a lot more enjoyable, reflective and effective towards creating an engaging piece of theatre." (student essay)

It is clear from systematic analysis of the two surveys, focus groups, and blogs, that students overall enjoyed the learning associated with the group blog work, as well as the unit as a whole. For learning to occur, to be efficient and enjoyable, the educational design needs to be integrated with the support and facilitation offered by the teacher. The learner experience survey, which provided feedback on the whole unit, not only the blogging task (see Table 2), indicated that the goals and standards for the unit were clear, the unit was challenging, the assessment was set at the appropriate level, the workload reasonable and the feedback timely. The blogging assignment was only one part of the unit, but as a key component of communication in tandem with classroom workshops, there is evidence to suggest that it was an important supporting mechanism.

Table 2: Summary of learner experience survey results $(n=20)$

\begin{tabular}{|l|c|c|c|}
\hline \multicolumn{1}{|c|}{ Criteria } & Strongly agree & Agree & Neutral \\
\hline Clear goals and standards & 10 & 9 & 1 \\
\hline Organisation & 10 & 9 & 1 \\
\hline Learning support & 10 & 8 & 2 \\
\hline Intellectual challenge & 6 & 10 & 4 \\
\hline Appropriate assessment & 8 & 10 & 2 \\
\hline Feedback & 7 & 11 & 2 \\
\hline Appropriate workload & 10 & 8 & 2 \\
\hline
\end{tabular}

\section{Choice of technology}

The choice of technology was based on an assessment of several social networking tools. We considered traditional learning management system (LMS) discussion boards to have insufficient functionality for our purposes, even though for other contexts they had proved very effective for assessable discussions. In this context however, we wanted to use the multimedia affordances of the web, and improve the visual and imaginative environment.

At first there seemed a strong case for the use of a wiki, as the key function of a wiki is provision of a collaborative, editable web space (e.g. see Godwin-Jones, 2003). However, even though a record of all revisions is retained on a wiki, the format for displaying those revisions was unsuitable for the drama assessment task. The history of discussion and negotiation had to be clearly visible and accessible: the journey of each student was as important as the final product. Mostly on a wiki it is the final product that is of greatest importance. Sites like Facebook and MySpace were considered 
to be too inter-connected with students' social lives, and the slightly more 'detached' blogging space was considered a better choice.

As the University's LMS blogging tool (Blackboard/WebCT) provided limited support for the overall aesthetic of the blog, an element considered important for student engagement with the online learning environment, the final choice was made between two blogging applications, Blogger and WordPress. (See Table 3.) We were satisfied that either of the two blogging tools would enable sufficient privacy for student assessments, as although the blogs had a public URL, they were not included in search engines or public blog listings, and moderator rights allowed for deletion of inappropriate posts, if necessary. WordPress provided the greatest variety of templates, so ultimately it was chosen.

Table 3: Comparison of selected technologies for collaborative blogging

\begin{tabular}{|c|c|c|c|c|c|c|}
\hline Name & Type & \begin{tabular}{|c|} 
Attach (a) \\
PDF, image \\
and text files; \\
(b) video and \\
audio files
\end{tabular} & $\begin{array}{l}\text { Embed } \\
\text { You- } \\
\text { Tube } \\
\text { clips }\end{array}$ & \begin{tabular}{|c|} 
Display \\
images \\
within the \\
text of blog
\end{tabular} & $\begin{array}{l}\text { Control of } \\
\text { privacy and } \\
\text { authoring } \\
\text { permissions }\end{array}$ & Comments \\
\hline Wiki & $\begin{array}{l}\text { Collabor- } \\
\text { ative } \\
\text { editable } \\
\text { web pages. }\end{array}$ & $\begin{array}{l}\text { (a) Yes } \\
\text { (b) Yes - if } \\
\text { server capa- } \\
\text { city allows }\end{array}$ & Yes & Yes & $\begin{array}{l}\text { Yes - public, but } \\
\text { usually requires } \\
\text { a password for } \\
\text { editing rights }\end{array}$ & $\begin{array}{l}\text { The record of } \\
\text { changes to the wiki } \\
\text { can be tracked, but } \\
\text { format not suitable } \\
\text { for this assessment. }\end{array}$ \\
\hline $\begin{array}{l}\text { Blackboard } \\
\text { WebCT } \\
\text { (learning } \\
\text { manage- } \\
\text { ment } \\
\text { system, } \\
\text { LMS) }\end{array}$ & $\begin{array}{l}\text { Licence } \\
\text { paid by } \\
\text { university. } \\
\text { Blog tool } \\
\text { within } \\
\text { suite of } \\
\text { tools on } \\
\text { LMS. }\end{array}$ & \begin{tabular}{|l} 
(a) Yes \\
(b) Not \\
within the \\
blog, but can \\
be linked via \\
URLs or \\
other LMS \\
tools.
\end{tabular} & Yes & \begin{tabular}{|l|} 
No - but \\
can link to \\
multimedia \\
hosting \\
sites via \\
URL, eg \\
YouTube, \\
Slideshare, \\
Bubbleshare, \\
Flikr
\end{tabular} & $\begin{array}{l}\text { Yes - users must } \\
\text { register with the } \\
\text { LMS course and } \\
\text { blog is complet- } \\
\text { ely protected } \\
\text { behind a secure } \\
\text { password. }\end{array}$ & $\begin{array}{l}\text { Blog is like an } \\
\text { unthreaded, text } \\
\text { based discussion } \\
\text { board. Limited } \\
\text { multimedia } \\
\text { integration is poor } \\
\text { compared with } \\
\text { other available } \\
\text { social networking } \\
\text { tools. }\end{array}$ \\
\hline Blogger & $\begin{array}{l}\text { Free blog } \\
\text { space. If } \\
\text { more } \\
\text { server } \\
\text { capacity is } \\
\text { required } \\
\text { over basic } \\
\text { limit, the } \\
\text { space must } \\
\text { be paid for. }\end{array}$ & $\begin{array}{l}\text { (a) Yes } \\
\text { (b) Not on } \\
\text { the free blog; } \\
\text { extra server } \\
\text { space must } \\
\text { be bought to } \\
\text { allow this. }\end{array}$ & Yes & \begin{tabular}{|l|} 
Yes - and \\
can link to \\
other \\
media \\
hosting \\
sites.
\end{tabular} & $\begin{array}{l}\text { Yes - control so } \\
\text { students cannot } \\
\text { edit/ delete } \\
\text { others' comm- } \\
\text { ents, and moder- } \\
\text { ator controls. } \\
\text { Blog has public } \\
\text { URL but this is } \\
\text { not included in } \\
\text { search engines } \\
\text { or public } \\
\text { listings. }\end{array}$ & $\begin{array}{l}\text { Customisable } \\
\text { templates provide } \\
\text { interesting } \\
\text { networking space. } \\
\text { No problem with } \\
\text { advertising - only } \\
\text { allowed if user } \\
\text { permits. }\end{array}$ \\
\hline Wordpress & $\begin{array}{l}\text { As for } \\
\text { Blogger }\end{array}$ & $\begin{array}{l}\text { As for } \\
\text { Blogger }\end{array}$ & Yes & $\begin{array}{l}\text { As for } \\
\text { Blogger }\end{array}$ & As for Blogger & As for Blogger \\
\hline
\end{tabular}

Students were given an hour of training on the use of the blogging platform. They opened a personal account and set up an individual blog, logged on to their group blog, and practised submitting text, adding URLs and small files. Each group selected a template. Every student had their own blog to 'play' with the technology, as well as collective ownership of the 'playbuilding blog'. Support documentation was provided via a frequently asked questions (FAQ) sheet, and two instructional videos from the 
video sharing and hosting site, YouTube. Few students referred to the support documentation, however, which suggests that the software was generally intuitive. Further, blog entries also show that students often resolved technical issues within their own groups, such as resizing photographs or uploading multiple photos. As all students needed to reach a certain level of competency by the end of the one hour of training, and to have set up their group blogs ready for discussions the following week, the training was compulsory. Issues which impacted on the training and orientation to the task included relatively trivial things such as choosing a suitable username and password, the name to be given to each group blog, and the choice of template to suit the forthcoming performance and chosen genre.

During the design phase of the project, issues relating to group administration and management were investigated. We were concerned that problems might arise in the group context that would not necessarily arise were each blog managed by individual students. For example, it was essential that students not delete or override the work of others. At the same time, we did not want to create an onerous moderation regime for the unit coordinator. Therefore, students were required to accept responsibility for their own blogs and postings, the unit coordinator did not approve comments before they were published, and students were given lower level "authoring" rights, rather than "editing" rights. Authoring rights meant that students could edit, publish and delete their own posts, and upload files, but they could not perform these functions on anyone else's posts or comments. Any rights or roles could have been upgraded if required, but ultimately this was not necessary. As a precaution against misadventure or loss, students were cautioned to make backup copies of all their work and create longer postings in a word processor before uploading to the live site.

Students quickly developed creative solutions to most issues with the technology. For example, large files could not be uploaded to the WordPress blog unless a fee was paid for additional server space over and above the free $10 \mathrm{MB}$ allocation. In practice, extra space was not required for each group as students simply linked to other free multimedia hosting sites as necessary. In order to submit multiple image files simultaneously to the blog in one action, rather than uploading a series of separate files, one group of students uploaded an album of their rehearsal photos to Facebook, and linked the photos via URL to their blog. Another student asked a friend to record sound files for the performance, load them onto an audio hosting site and then linked these to the blog via a URL. Many students embedded videos sourced from YouTube into their blog entries, while others recorded their own videos of rehearsals, opened a YouTube account, and shared their work as resources for discussion and development of the playbuilding process.

The result was an embedded, visually interesting and media rich environment, not merely a space full of written text that would have been the case had, for example, we used only a traditional LMS discussion board. Analysis of the students' comments on the blogs and review of the collage of images and visual elements that comprised the student-generated learning space suggests that there was a performative aspect to the blogging (Figure 2 shows one of the blogging spaces). On one level students contributed content and ideas about performance elements (such as lighting, stage design, costumes choices etc), and on another level there was an aspect of performance in that contribution. Students were simultaneously actors and audience, designers and consumers. This interesting area of discussion, however, goes beyond the scope of this paper and is certainly material for further research. 


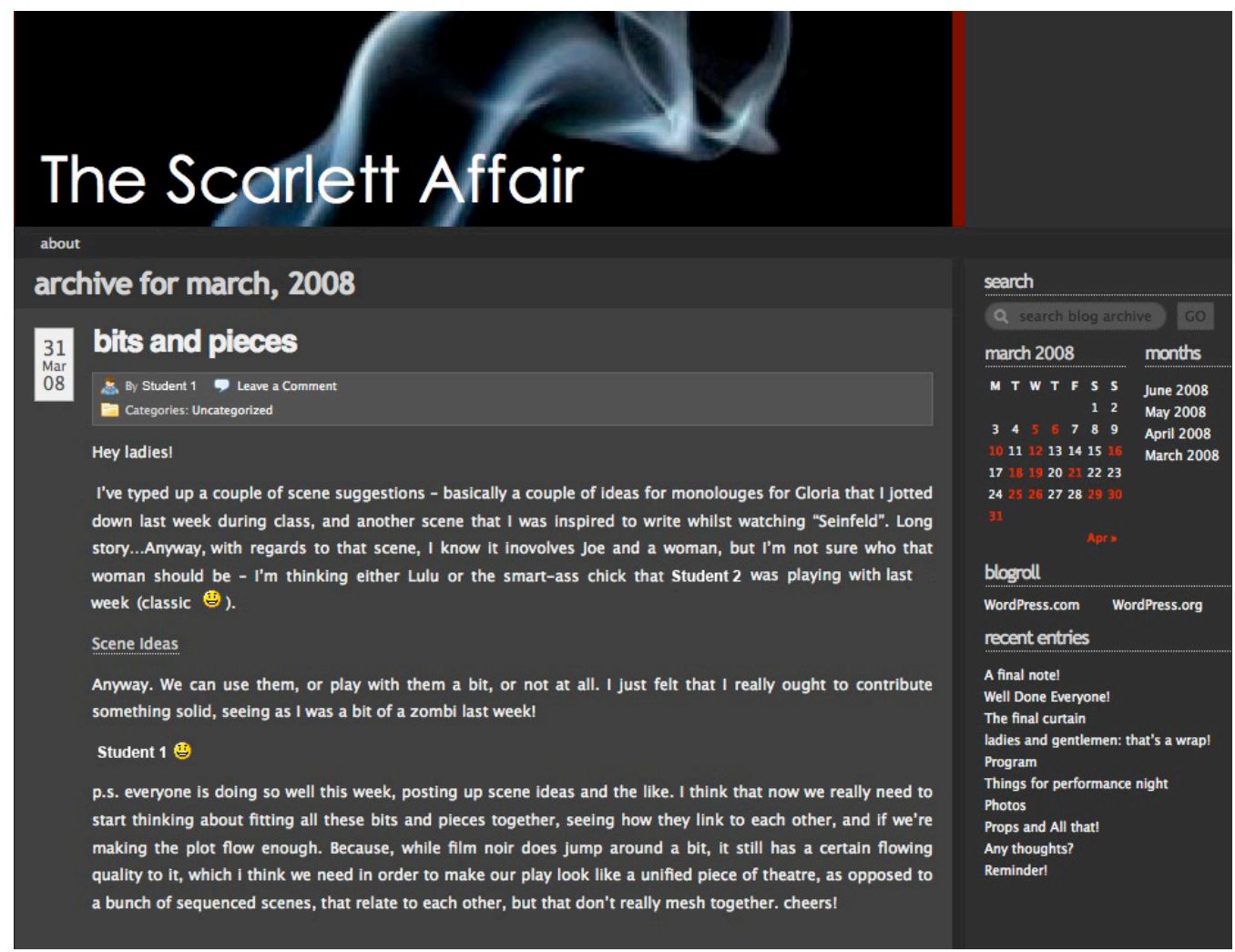

Figure 2: Example of the blogging interface

It was clear from analysis of the blog entries and focus group comments that the majority of students contributed to the blogs so that their study commitments fitted with their regular use of other technologies; study and socialisation became enmeshed, to some extent. For example:

To be honest, if we were writing on the blog we'd probably have the Facebook window open anyway, and we were doing it at the same time, so combining those sort of technologies ... [I'd say] 'Yes, I can use this! This will be brilliant!' (focus group)

Most students were enthusiastic about the technology, and only one or two felt they did not benefit as much as others. This minority is represented by sentiments such as: "Good to know about the technology, but more tedious than useful for process" (blog survey).

In setting the blogging task we made assumptions about the student's readiness for the technology, given our own experience with similar cohorts of students and evidence from the literature (Kennedy, Dalgarno et al., 2008; Kennedy, Judd et al., 2008). Evidence from the surveys, the focus groups and blogs suggested that while students were generally open to using the new social networking technologies, their practical experience of specific applications was inconsistent across the cohort. This correlates with the Kennedy studies which warn of the dangers of overstating the use and popularity of new technologies amongst those classified as "digital natives" (Prensky, 2001). When asked "Which, if any, of the following social networking technologies do 
you use on a regular basis - daily or every few weeks?", the responses were those given in Tables 3 and 4 . The three most regularly used technologies in this cohort were Facebook or MySpace, YouTube and mobile phones (19/21), and more than half of the students were using at least three of the technologies listed in Table 3 on a regular basis. Half of the students also used Skype, MSN or some other chat tool regularly. Importantly, only 3 of the 21 claimed to have blogged before.

Table 3: Use of social networking technologies $(\mathrm{n}=21)$

\begin{tabular}{|l|c|}
\hline \multicolumn{1}{|c|}{ Technology } & $\begin{array}{c}\text { Students who used the } \\
\text { technology regularly }\end{array}$ \\
\hline Facebook or MySpace & $\mathbf{1 9}$ \\
\hline Blog & 3 \\
\hline $\begin{array}{l}\text { MSN, Skype, or other } \\
\text { chat tools }\end{array}$ & 10 \\
\hline Second Life & 0 \\
\hline YouTube & $\mathbf{1 9}$ \\
\hline $\begin{array}{l}\text { Massively multiplayer } \\
\text { online role-playing game }\end{array}$ & 1 \\
\hline Mobile phone & $\mathbf{1 9}$ \\
\hline Other & 1 \\
\hline
\end{tabular}

Table 4: Use of multiple technologies $(\mathrm{n}=21)$

\begin{tabular}{|l|c|}
\hline \multicolumn{1}{|c|}{ Multiple applications } & $\begin{array}{c}\text { No. of } \\
\text { students }\end{array}$ \\
\hline $\begin{array}{l}\text { Students who used 1 of } \\
\text { the technologies listed }\end{array}$ & 2 \\
\hline $\begin{array}{l}\text { Students who used 2 of } \\
\text { the technologies listed }\end{array}$ & 0 \\
\hline $\begin{array}{l}\text { Students who used 3 of } \\
\text { the technologies listed }\end{array}$ & $\mathbf{1 1}$ \\
\hline $\begin{array}{l}\text { Students who used 4 of } \\
\text { the technologies listed }\end{array}$ & 5 \\
\hline $\begin{array}{l}\text { Students who used 5 of } \\
\text { the technologies listed }\end{array}$ & 2 \\
\hline
\end{tabular}

In terms of future use of these technologies, students were asked if, in the future, they would like their assessments (such as playbuilding) linked more closely with their Facebook activities, or other social networking tools. On reflection, they said no, they would like to keep a manageable distance between their social life and study life.

No, I like the fact the blog was a bit separate, actually, but it was still a really, easygoing, nice place to have the discussion, it was still very informal. (focus group)

Given the power of networking tools like Facebook, it is probably wise to draw a boundary, to keep a level of privacy for both the teacher and the student.

\section{Conclusion}

However well designed, the replacement of the individual journal with the group blogging assessment task was a risk. Nonetheless, the challenge of setting up the learning context so students could work collaboratively in a blended learning environment (online and face to face) to build a theatre performance over a period of four months was met. In answer to the research questions, the following general points were concluded.

\section{Differences and similarities between group blogging and individual journal reflection}

- The 'conversational' and public nature of the group blog strengthened the depth of analysis and reflection. As a group member each student could not avoid participation in the debate and negotiation of ideas without their 'absence' being 
noticed. This depth of analysis is rare in the more private and less openly challenged individual reflective journals.

- Both the individual reflective journal and the group blog can focus on analysis and evaluation of process and outcomes. However, the blog is more likely to help with 'housekeeping' issues and facilitation of process than the individual journal.

- Students had collective ownership of the online space in which they shared resources and creative ideas; the private journal is an individual venture. Both 'spaces' can be developed as student centred environments, where students have full control and autonomy.

- Provision of explicit criteria which encourage analysis and reflection, rather than uncritical stream of consciousness writing, can improve student outcomes from individual reflective journals and group blogs.

- Both spaces are suitable vehicles to document the playbuilding process, personal and theoretical reflection. The blog is also a space for documenting group reflection.

- Facilitation of process and critique is a key role for the teacher in either space.

\section{Engagement}

- There were intrinsic reasons for the students to engage with the critique generated by group members, as the authentic, real world task - to build and perform a play encouraged a high level of engagement which was not merely attributable to assessable requirements.

- The more sophisticated multimedia affordances of the web (compared with print based journals) are advantageous in that they allow students to generate and document ideas about production and performance which are both engaging and inspiring.

- There may be performative aspects relating to students' collaborative public contribution to the blogging space which lifts the level of engagement beyond that which is commonly found in individual reflective journals.

\section{The limitations and benefits of group blogging as a collaborative form of assessment}

- Unless specific word limits and criteria are set, the blogs could require an unrealistic amount of time for the unit coordinator to read, cross-reference and mark.

- The format is adaptable for other disciplines and contexts which require collaboration towards a final production.

The project was repeated in 2009 with similar outcomes, and it is anticipated that group blogging will be retained for future offerings of the unit. It became clear that optimal group size was probably about eight students: this suited management of practical rehearsals and contributions to the blogs. There were sufficient members to create lively and productive debate on and off line, but not too many students so that the learning outcomes for a project requiring group cohesion and complex problem solving skills could be achieved within the time span of a semester.

As students in higher education increasingly prioritise work commitments over and above study commitments, there is a need to focus attention on student engagement. This study indicates that the incorporation of a media rich, group blogging task and 
the use of social networking technologies within a well structured, but flexible learning environment, supports the documentation of group work and creative processes for playbuilding (group devised theatre). Its potential for improving learning and teaching outcomes in other disciplines should be explored by other educators.

\section{References}

Anderson, P. (2007). What is Web 2.0? Ideas, technologies and implications for education. Joint Information Systems Committee (JISC) Technology and Standards Watch, February. http: / / www.jisc.ac.uk/media/ documents / techwatch/tsw0701b.pdf [viewed 15 Dec 2008]

Bailin, S. (1996). Philosophical research in drama education: The case of creativity. Research in Drama Education, 1(1), 79-86.

Chong, E. (2008). Harnessing distributed musical expertise through edublogging. Australasian Journal of Educational Technology, 24(2), 181-194. http: / / www.ascilite.org.au / ajet/ajet24/ chong.html

Dacre, K. \& Mackey, S (1999). Self-interpreting animals: Action research and the reflective drama journal. Research in Drama Education, 4(4), 51-71.

Godwin-Jones, R. (2003). Emerging technologies. Blogs and wikis: Environments for on-line collaboration. Language Learning \& Technology, 7(2), 12-16. http:/ /llt.msu.edu/vol7num2/pdf/emerging.pdf

Hurlburt, S. (2008). Defining tools for a new learning space: Writing and reading class blogs. Journal of Online Learning and Teaching, 4(2), 182-189. [verified 31 Oct 2009] http:/ / jolt.merlot.org/vol4no2/ hurlburt0608.htm

Instone, L. (2005). Conversations beyond the classroom: Blogging in a professional development course. In Balance, Fidelity, Mobility: Maintaining the momentum? Proceedings ASCILITE Brisbane 2005. http: / / www.ascilite.org.au/conferences/brisbane05/blogs / proceedings/34_Instone.pdf

Kember, D. \& Kelly, M. (1993). Improving teaching through action research. Campbelltown NSW: Higher Education Research and Development Society Australasia (HERDSA).

Kennedy, G., Dalgarno, B., Bennett, S., Judd, T., Gray, K. \& Chang, R. (2008). Immigrants and natives: Investigating differences between staff and students' use of technology. In Hello! Where are you in the landscape of educational technology? Proceedings ascilite Melbourne 2008. http: / / www.ascilite.org.au/ converences/melbourne08/procs/kennedy.pdf

Kennedy, G. Judd, T., Churchward, A., Gray, K. \& Krause, K-L. (2008). First year students' experiences with technology: Are they really digital natives? Australasian Journal of Educational Technology, 24(1), 108-122. http: / / www.ascilite.org.au/ajet/ajet24/kennedy.html

Laurillard, D, (2002). Rethinking university teaching: A conversational framework for the effective use of learning technologies. (2nd Ed.) London: Routledge Falmer.

Lave, J. \& Wenger, E. (1991). Situated learning: Legitimate peripheral participation. Cambridge: Cambridge University Press.

McTaggart, R. (1991). Principles for participatory action research. Adult Education Quarterly, 41(3), 168-187. 
Magnat, V. (2005). Devising Utopia, or asking for the moon. Theatre Topics, 15(1), 76-86. [verified 31 Oct 2009] https: / / people.ok.ubc.ca/ creative/VirginieM/Devising\%20article $\% 20$ by $\% 20$ Virginie $\% 20$ Magnat.pdf

Nardi, B. A., Schiano, D. J. \& Gumbrecht, M. (2004). Blogging as social activity, or, would you let 900 million people read your diary? Proceedings of the 2004 ACM Conference on Computer Supported Cooperative Work. pp.222-231.

Nicholls, J. \& Philip, R. (2001). Drama online. Australian Journal of Educational Technology, 17(2), 150-168. http:/ / www.ascilite.org.au/ajet/ajet17/nicholls.html

O’Toole, J. (2006). Doing drama research. Queensland: Drama Australia.

Philip, R. \& Nicholls, J. (2007). Theatre online: The design and drama of e-learning. Distance Education, 28(3), 261-279.

Pierse, L. (1993). Theatre sports downunder. Sydney: Improcorp Australia.

Prensky, M. (2001). Digital natives, digital immigrants. On the Horizon, 9(5). http:/ / www.marc prensky.com/writing/Prensky\%20-\%20Digital\%20Natives,\%20Digital\%20Immigrants\%20-\%20Part1.pdf

Simons, J. (2004). Playbuilding: More than the sum of its parts. In M. Mooney \& J. Nicholls (Eds.), Drama journeys: Inside drama learning. Sydney: Currency Press.

Tekinarslan, E. (2008). Blogs: A qualitative investigation into an instructor and undergraduate students' experiences. Australasian Journal of Educational Technology, 24(4), 402-412. http: / / www.ascilite.org.au/ajet/ajet24/ tekinarslan.html

Williams, J. B. \& Jacobs, J. (2004). Exploring the use of blogs as learning spaces in the higher education sector. Australasian Journal of Educational Technology, 20(2), 232-247. http:/ / www.ascilite.org.au/ajet/ajet20/williams.html

Robyn Philip, Academic Developer and Educational Designer

Teaching and Learning Quality Group

Charles Darwin University, NT 0909, Australia

Email: robyn.philip@cdu.edu.au

Jennifer Nicholls, Senior Lecturer

Institute of Early Childhood, Faculty of Human Sciences

Macquarie University, NSW 2109, Australia

Email: jenny.nicholls@mq.edu.au 